\title{
Changing models of research to inform educational policy
}

Kathy Sylva ${ }^{a *}$, Brenda Taggart $^{\mathrm{b}}$, Edward Melhuish $^{\mathrm{c}}$, Pam Sammons $^{\mathrm{d}}$ and Iram Siraj-Blatchford ${ }^{\mathrm{b}}$

${ }^{a}$ Department of Educational Studies, University of Oxford; ${ }^{\mathrm{b}}$ Institute of Education, University of

London; ' Institute for the Study of Children, Families \& Social Issues, Birkbeck, University of

London; ${ }^{\mathrm{S}}$ School of Education, University of Nottingham

\section{Abstract}

This paper explores changes in the way that educational researchers engage with policy-makers in England. The traditional relationship between research and policy was linear, with funders supporting the efforts of researchers, who carried out research and then disseminated it to those responsible for shaping and implementing policy. This model of 'knowledge transfer' is fast being supplemented and sometimes replaced by one of 'knowledge exchange' as policy-makers participate in new forms of research. 'Knowledge exchange' consists of 'collaborative problem-solving between researchers and decision-makers that happens through linkage and exchange. Effective knowledge exchange involves interaction between decision-makers and researchers and results in mutual learning through the process of planning, producing, disseminating, and applying existing or new research in decision-making' (Canadian Health Services Research Foundation, 2007).

This paper uses one large-scale English study to illustrate the new relationship between research and policy. The Effective Pre-school and Primary Education (EPPE) project is a longitudinal study of the effects of pre- and primary school on the academic and social development of more than 3,000 children in England (Sylva, Melhuish, Sammons, Siraj-Blatchford \& Taggart, 2004). Compared to children with no pre-school experience children who attended preschool had better academic and social behavioural outcomes at age 5 (Sammons, Sylva, et al., 2002; Sammons, Sylva, et al., 2003). By age 7 they still showed higher academic scores when compared to children without pre-school (Sylva et al., 2004). These findings have been used as part of the 'evidence base' for UK policy on universal pre-school provision as well as targeted services in disadvantaged communities, for example, Sure Start and Children's Centres.

From the earliest days of the study researchers worked in partnership with policy-makers. Although the overall design was agreed at contract-stage, major modifications to sampling, assessments, and analyses were made as the study progressed. The researcher/policy-maker engagement continued throughout the study and consisted of sustained interaction, shared decision-making and mutual respect. Supportive organisational structures allowed two-way exchange and decision-making. Although the researchers were responsible for scientific integrity in all phases, there was shared ownership of the findings with regular and collaborative review and amendment to suit emerging policy needs. The EPPE project was one of the first in the UK to work interactively with government partners in the shaping of both 'research' and 'policy' outputs. This partnership enabled the research to have a significant impact on UK policy. The paper concludes with discussion of how the Furlong and Oancea 'quality assessment framework' can be applied to research based on policy partnerships.

Keywords: Research partnerships, Policy, Early Years 


\section{Changing models of research}

\section{Background to the study}

This paper focuses on a single English research study, the 'Effective Provision of Pre-school and Primary Education' (EPPE), to illustrate new forms of partnership working between those who design and conduct research and those who use it for policy. It will be argued that the blunt differentiation of roles into 'researcher' and 'user' impedes the capacity of research to be closely aligned with policy and of policy to be shaped and implemented in the light of research. EPPE can be considered an example of 'use-inspired basic research' (Furlong \& Oancea, in press, this volume).

The late 1990s saw major debates on whether or how national/local policy should be guided or informed by research (Hargreaves \& Reynolds, 1989; Hillage, Pearson, Anderson \& Tamkin, 1998; Cabinet Office, 1999; Strategic Policy Making Team, 1999; Sebba, 2000). At the turn of the century vociferous criticism was aimed at the failure of research in education (and also social care and criminal justice) to have a serious impact on either policy or practice. In education and social care, although slightly less in health, the debate was particularly heated (Fitz-Gibbon, 1999; Macdonald, 1999). Some criticism related to the quality of the research itself (Tooley, 1998) but other criticisms pertained to the general isolation of academic 'ivory towers'. Five years on, there is a broad consensus that policy can and does benefit from empirical research findings (Davies, Nutley \& Smith, 1999, 2000; Walter, Davies \& Nutley, 2003; Feuer \& Smith, 2004; Furlong \& Oancea, in press, this volume). Although the precise kind of research that is most useful or appropriate for a range of policy areas is contested, the proliferation of seminars, conferences, and publications attests to keen interest in the role of research in policy. Research studies are now mentioned prominently in policy documents in education and footnotes tempt the reader with a forest of 'relevant' or 


\section{Changing models of research}

'background' research publications. Service effectiveness has not escaped; it too is subjected to research scrutiny and often this takes the form of empirical evaluation.

Since these hard-hitting criticisms (and before them, see Huberman, 1993), there have been many developments that have strengthened the relationship between research and practice through direct engagement with practitioners. One of the most wide ranging and ambitious examples has been the ESRC Teaching and Learning Research Programme (www.tlrp.org) which focused on learning across the life course and how research evidence can inform practice. Another example is the Centre for the Use of Research and Evidence in Education (CUREE; www.curee-paccts.com/index.jsp) that was set up in 1997 to help practitioners access and make more effective use of research findings. A third example would be what Nutley, Percy-Smith and Solesbury (2003) refer to as the "best example' of partnership research in education: the 'School Based Research Consortia' led by the Teacher Development Agency. In this initiative teachers received research grants to carry out small scale research projects with the stated aim of improving practice through research. These are just a few of the many initiatives centred on partnerships between researchers and practitioners. Although initiatives on practitioner/researcher partnerships are on the increase there have been fewer partnerships between researchers and policy-makers, and consequently the literature on applied and practice-based research tends to focus on partnerships between researchers and practitioners rather than researchers and policy-makers. The Furlong and Oancea paper that opens this volume provides most of its examples from the links between researchers and practitioners - and very few on links between researchers and policy-makers.

\section{Partnership working}




\section{Changing models of research}

\section{Models of the relationship between policy-makers and researchers}

Furlong and Oancea (in press, this volume) refer to 'two communities', one in academia and the other in the 'real world'. Traditionally research and policy was conceived as a linear relationship characterised by knowledge transfer between these worlds (see Figure 1). Common in this model is 'Blue Skies' research that precedes policy. Policy-makers then use Blue Skies research findings to create 'better' or more effective (or equitable, etc.) policies.

[insert Figure 1 here]

A modification to the one-way linear model is a two-way model (Figure 2) exemplified by evaluation work in which the policy-makers commission an evaluation, which is then carried out by researchers working to a specified set of objectives and timetable.

[Insert Figure 2 here]

Policy-makers are part of the research from the beginning and the two different teams often communicate with one another, but each has very separate roles and decisions about design issues are taken by the researchers. This model is also characterised by knowledge transfer. In both models described above the two clearly defined communities eye each other across a wide gap.

A third model is a partnership one (Figure 3) which is characterised by knowledge exchange rather than knowledge transfer. In this new model researchers and policy-makers work together in shaping, implementing and disseminating the research. The knowledge is jointly created and evaluated. The 


\section{Changing models of research}

partnership is an inter-organisational one and the partners work together from the initial design of the study through to the dissemination of the findings.

[Insert Figure 3 here]

Knowledge exchange (not knowledge transfer) is:

Collaborative problem-solving between researchers and decision makers that happens through linkage and exchange. Effective knowledge exchange involves interaction [italics added] between decision makers and researchers and results in mutual learning through the process of planning, producing, disseminating, and applying existing or new research in decision-making. (Canadian Health Services Research Foundation, 2007)

Models 1 and 2 rarely have an impact on practice. In a systematic review in the health field Innvær, Vist, Trommald and Oxman (2002) identified face-to-face interactions as the only factor that has consistently been shown to influence the use of research knowledge by health system managers and public policy-makers. In another systematic review of health, social care, criminal justice and education, Walter, Nutley and Davies (2003) came to a similar conclusion. However, Ross, Lavis, Rodriguez, Woodside, and Denis (2003) commented that 'efforts to foster greater interactions between researchers and decision-makers have largely focused on involving decision-makers in the research process, not on involving researchers in the decision-making process or in stand-alone interactive processes' (p. 26).

\section{Research evidence on partnership working}

One of the most detailed studies on the 'exchange' relationship between researchers and policymakers was carried out by Golden-Biddle et al. (2003). They reported on a 30 month case study in 


\section{Changing models of research}

which they observed and interviewed partners in one innovative partnership funded by the Canadian Health Services Research Foundation and the Alberta Heritage Foundation for Medical Research. The research partnership aimed at 'advancing knowledge on implementing and sustaining organisation change for use by decision makers in the health sector' (Golden-Biddle et al., 2003, p. 21). Early in the proposal writing stage the researchers sought decision-making partners to help them frame the research questions. The decision-makers continued to provide a 'strong voice in defining the particular research areas now being investigated' (ibid, p. 21). Golden-Biddle et al. (2003) concluded that the policy potential of the project they studied had been increased through the partnership with policy-makers.

Golden-Biddle and colleagues point to an unusual equality and awareness of each others' roles. A policy-maker speaks of the 'old way':

The stance that researchers take to those they study is really important. As decision-makers, we have worked with some researchers who convey that the practice of health care is secondary to research in health care. Their stance was more of 'this [research] is good for you' rather than how can we work together on mutually important issues. A genuine and mutual respect was missing in these working relationships. (Golden-Biddle et al., 2003, p.22)

Another policy-maker describes the 'new way': 'The researchers do not hang around together during meeting breaks or lunchtime. Rather, they mingle with us and they sit at lunch so they can interact individually' (Golden-Biddle et al., 2003, p.22).

Finally, a researcher speaks of the partnership:

As we begin to interact, we gain an awareness and greater understanding of 'their' world and who they are, just as they gain a better understanding of 'our' world and who we are. We see first hand how decision-makers gain 


\section{Changing models of research}

important knowledge in experience about health care delivery. We also become aware of the challenges, joys, frustrations and outright fatigue people in health organisations face as they attempt to change health care practice. And finally, we gain an appreciation for the local knowledge so necessary to effectively implementing real change on the ground. (Golden-Biddle et al., 2003, p.22)

In another Canadian study of seven partnerships in health, Ross et al. (2003) identified three different types of policy-maker involvement in research. These included the role of formal supporter when decision-makers are not involved in the process, responsive audience where policy-makers are actively involved and respond when the researchers ask for information or tactical advice, and integral partner. In this last, the policy-makers are actively involved in most stages of the research process, sharing in scientific decisions.

In a cross sector review, Walter, Nutley and Davies (2003) describe how the new exchange partnerships operate:

[They] carry out their shared work through informal emails and telephone calls, with meetings when appropriate. They need to pay careful attention to formal minutes and record keeping so that each side knows what has been decided or done, with dates of decisions and names of persons who did each task. There may be site visits to each other's offices, or even co-location. (Finally) personnel may move from one to the other headquarters for specified periods.

\section{Research on the 'benefits' and 'costs' of research partnerships}

The Ross et al. (2003) study of seven partnerships suggests that researchers gained a greater understanding of the decision-making environment through their interactions with policy-makers: 


\section{Changing models of research}

We're gaining much more than data from this project. In the partnership that's developed, the relationship, we're gaining a real understanding of the challenges of implementation, the world that these decision-makers live in every day and how they deal with the complexities and challenges. (p.30)

For policy-makers, involvement in the research process made them more reflective about their activities: '[Our involvement] has helped us put together a big picture - the impact of what's going on in our organization'.

However, some 'costs' were reported for researchers, both operationally - 'it certainly takes more time and it's been way more challenging to do applied research involving decision-makers than I'd anticipated' (Ross et al., 2003, p. 30) - and professionally:

Every minute I spend talking with these people and doing these activities...is a minute I'm not spending writing for publication that is rewarded in my environment....when we work on local needs...it is not evident that we are going to be able to publish in the New England Journal of Medicine. (ibid, p. 30)

These new partnerships require a long-term commitment. Ross et al. (2003) comment that 'partnerships require investment... [They] need to be "tended'" (p. 31). Other than the costs, mainly time, identified above, there appear to be few other losses; Ross et al. (2003) comment: 'sacrificing the independence of the research was not among the costs identified for decision-maker involvement' (p. 31). Furthermore, Ross et al. (2003) found that 'the benefits of involving decisionmakers in the research process outweighed the costs, especially in the long run' (p. 31). As one policy-maker noted: 'involvement might slow down researchers' work through some phases, but in the long run researchers who collaborate are further along than they'd be otherwise' (p. 31). 


\section{Changing models of research}

\section{Barriers to research and policy partnership}

Despite Ross et al.'s (2003) overall positive reporting on new partnerships, Walter (2005) outlines some significant barriers to effective partnership working. These are:1) resources of time, people, skills; 2) the need to balance competing agendas between the partners; 3) problems of power differentials and the need to manage these; and 4) the need for partners to collaborate but to maintain independence at the same time. The remainder of this paper illustrates how the EPPE team and their funders, the Department for Education and Skills (DfES), overcame some of these barriers in order to foster 'knowledge exchange' which had a major impact on national policy and even went beyond the original research aims to inform policy change in other areas.

\section{The EPPE project: An example of a 'knowledge exchange' partnership}

The EPPE (1996-2008) research is the largest study in Europe on the effects of pre-school and primary school on the academic and social development of 3,000 children (Sylva, Melhuish, Sammons, Siraj-Blatchford \& Taggart, 2004). EPPE was funded by the Department of Education and Employment (later the DfES) to inform policy on early education in England: its nature, effects, and cost effectiveness. EPPE supplements quantitative findings with qualitative ones (Sammons et al., 2005; Siraj-Blatchford, Sammons, Sylva, Melhuish \& Taggart, 2006), and this mixture resembles Gibbons and colleagues' 'Mode 2' model of knowledge production (Gibbons et al., 1994). The EPPE findings demonstrated that pre-school children had better academic and social behavioural outcomes at age 5 compared to children who did not attend pre-school (Sammons, Sylva, et al., 2002; Sammons, Sylva, et al., 2003). By age 7 they were still showing higher academic attainment (Sylva et al., 2004). As well as reporting on the positive impact of pre-school, EPPE explores the associations between pre-school, child, family and home characteristics that make a difference to a 


\section{Changing models of research}

child's life chances. Their findings on the importance of the home learning environment, in particular, have broken new ground (The Equalities Review, 2006). EPPE also identified effective practice and staffing.

\section{How the EPPE partnership works on the ground to overcome barriers}

From the earliest days of the study EPPE researchers worked in partnership with the policy-makers. In the Ross et al. (2003) typology EPPE operated with integral partners most of the time and with responsive partners the rest. Partnerships with policy-makers are not easy: the barriers described by Walter (2005) were encountered and addressed in a variety of ways. The following section of this paper addresses how these barriers were overcome while pointing to specific strategies that foster an environment that supports the use of research findings to inform and assist policy development. It is argued that the 'knowledge-exchange' partnership facilitated the direct use of EPPE findings in formulating policy.

Barrier 1: Resources of time, people, skills. The EPPE research is longitudinal, combines qualitative and quantitative methodologies, involves individual assessments of approximately 3,000 young children across the country, has repeated assessment time points, colleted data from families/pre-school/school settings, and tracks and maintains the whereabouts of a very mobile population. During the pre-school phase the project employed 30 researchers. Any one element of this research would require good management but the combination of all of these make EPPE a challenge for management and resourcing. 


\section{Changing models of research}

From the onset the research team and the DfES had very clear lines of management, delegation and lines of communication, not only between themselves but at the interface of the two partners. What marks EPPE out from other longitudinal studies is, that despite being a multidisciplinary team who work at a range of institutions, they are a 'real' rather than 'virtual' (internet based) team. The five principal investigators meet 'face-to-face' on a weekly basis, have a strong decision making culture and are task driven. This has been coupled with monthly meetings with policy partners where 'joint and negotiated decision making' takes place. The meetings with policy-makers have a negotiated agenda and 'action point' minutes. This is time-consuming and funders recognised the importance of this by making resources available for this level of co-operation.

Good management is needed if resources are to be used efficiently. The central role of the Research Co-ordinator (and linked operational manager at the DfES) provided an efficient channel for collective communications, and has avoided the misunderstanding that can occur in managing complex agendas across academic and governmental institutions. Supportive organisational structures, created jointly by researchers and policy-makers, allowed two-way exchange of information and efficient collective decision making.

Barrier 2: The need to balance competing agendas between the partners. In its baldest form, the EPPE researchers' initial agenda was to carry out and report on 'academic' research. This is often at odds with the need for policy-makers for 'instant' findings, transparent (and therefore) simple research methods, and findings that lend themselves to 'sound bites'. The EPPE team attempted to square this circle in two ways: the publication of technical papers summarising details of methods for an academic audience, and (2) resources adequate for scientific rigour in addition to time-consuming collaboration and dissemination of policy-oriented briefs. 


\section{Changing models of research}

An example of 'adequate funds' may be useful. Although the overall design was agreed early in the research cycle, major modifications to sampling, assessment instruments and analyses were made as the study progressed in order to be responsive to emerging policies. For example, 18 months after the start of the project it became clear that integrated provision and 'enhanced' nursery schools were going to feature in policy, something not originally anticipated in the sampling. The EPPE Steering Committee worked with the researchers to expand the original sample, enabling the researchers to recruit an additional 800 children from these providers. One year later, the researchers carried out new analyses of early care before 3 years, something not originally anticipated. In these cases the researchers accepted additional work in the research but negotiated additional funds to answer emerging policy questions that were not in the original contract.

Barrier 3: Problems of power differentials and the need to manage these. Nowhere is the power differential in the funder/researcher partnership more evident than in the 'ownership' of findings and their dissemination. Over the period of the research, although the researchers were responsible for scientific integrity in all phases of the research cycle (the epistemic dimension referred to in the Furlong \& Oancea paper), there was shared ownership of the findings because of regular and joint review of fieldwork and analysis. The DfES helped the research team 'keep up-to-date and relevant' through challenging review and interpretation. This often generated further policy questions from a wide range of government departments, which then led to additional analyses (see the economic dimension and 'value for money' discussion in Furlong \& Oancea, in press, this volume). The policy-maker partners helped the team to make research findings crystal clear to a range of stakeholders. The power differential between the policy-makers (with the money and the power) and the research team (with the expertise) was ameliorated through a culture of mutual respect, fostered 


\section{Changing models of research}

by a clear understanding of individual roles and responsibilities. A strong partnership was evident in the dissemination of findings through joint Ministerial Briefings and press launches for the public.

There is a separate 'power' agenda however that needs to be recognised in the structures associated with policy making across 'joined up' departments. Competing needs between different government departments (DfES funders, The Treasury, The Cabinet Office) require a high degree of 'joined-up' thinking and a flexible approach to the timetabling of research activities. Many government departments suggested research agendas to the EPPE team and their needs and timetables had to be prioritised with the policy partners.

\section{Barrier 4: The need for partners to collaborate but to maintain independence at the same time.}

The knowledge exchange mode of working between researcher and policy-makers can only be successful where each party maintains its own independence. The relationship can never be so 'cosy' as to jeopardise the integrity of the methods and interpretation. EPPE has experienced the need to adopt the position of truly 'independent' researchers, particularly in cases in which research findings did not fit comfortably with current policy. In the expansion of early years services to children younger than 3 years, EPPE reported some negative findings on early (and high hours) group care for a small number of young children. Although this led to some negative publicity for the government's expansion of child care, it did highlight the need for a better understanding of what constitutes 'quality' care for babies in pre-school settings. The researchers joined the government officials in 'managing' publication of findings. There was never an attempt to 'gag' the researchers.

Maintaining the impartiality of the EPPE research has required strong academic representation on the Steering Committee. In addition EPPE findings have been peer reviewed in academic publications. 


\section{Changing models of research}

The quality of the administration of the research has also been scrutinised though DfES review and audit, leading sometimes to improvements.

\section{The policy impact of the EPPE research findings}

EPPE had an acknowledged impact on policy (Inter-departmental Childcare Review, 2002; Every Child Matters [HM Treasury], 2003; DfES, 2004, 2005; HM Treasury, 2007). The Children Act (2004) refers to EPPE in many places, especially those setting forth the case of expanded services for young children and their families. The 'Policy Review of Children and Young People' (HM Treasury, 2007, p. 10) cites EPPE as the basis for many government services. Government guidance documents for teaching staff cite evidence of the EPPE findings as rationale for practice shifts, for example, the Sure Start Code of Practice (Sure Start, 2006). 'The EPPE study provides essential evidence which now underpins the work of the Sure Start Unit' (Head of Communications, Sure Start, DfES, 2003).

Two further examples of EPPE impact relate to the early identification of children with Special Educational Needs and effective early years pedagogy. These topics were part of 'add on' studies in which the EPPE researchers interrogated existing data (and sometimes collected new data) to produce two substantive add-on studies: The Early Transitions and Special Educational Needs (EYTSEN) Study (Sammons, Smees, et al, 2002; Sammons, Taggart et al., 2003a, 2003b; Sammons et al., 2004; Taggart et al., 2004, 2006) and the Researching Effective Pedagogy in the Early Years (REPEY) study (Siraj-Blatchford, Sylva, Muttock, Gilden \& Bell, 2002; Siraj-Blatchford et al., 2003). The findings of these two 'add on' studies have informed policy and practice related to SEN 


\section{Changing models of research}

in the Early Years and pedagogy in the Foundation Stage. Again, the add-on studies were not part of the original contract but emerged in response to policy needs.

In addition to reporting research evidence to DfES policy teams, EPPE offered policy advice to other arms of government: Qualifications and Curriculum Authority (formulation of the Curriculum Guidance for the Foundation Stage and Foundation Stage Profile); Parliamentary enquiries (House of Commons, 2000, 2004; Scottish Parliamentary Enquiry and Welsh Assembly); and to a range of Ministers and governmental departments (e.g., The Cabinet Office, The Department for Work and Pensions, The Paymaster General, The Chancellor of the Exchequer, Number 10 Delivery Unit, The Equalities Review, and the Secretary of State for Health, as well as a succession of Education Ministers). While advising the Treasury Cross Departmental Spending Reviews about the benefits of different forms of educational provision, the Treasury team prompted new statistical analyses that have enriched the findings (see Sylva et al., 2004, Appendix B). This is an example of policymaking partners enhancing the scientific scope of the study. A wide range of non-governmental policy documents cite the evidence from EPPE (Social Market Foundation, 2005; The Liberal Democrats, 2003).

\section{Why did EPPE have an impact on policy?}

It has been argued that the major impact of EPPE on policy was made possible through its 'knowledge exchange' partnership. By replacing linear models with those of 'knowledge exchange', EPPE has contributed to the 'transformational policy change' (Sylva \& Pugh, 2005) related to child care and education in the period 1997-2006. Sylva and Pugh (2005) suggest one reason for the large impact of the EPPE project: 'the research points to the separate and significant influence of (pre- 


\section{Changing models of research}

school and) the home learning environment. These aspects, quality and quantity of pre-school and home learning environment, are more susceptible to change through policy initiatives than family characteristics such as SES. Early childhood services are a powerful lever in reducing inequalities and the government used this message in 1999-2004 as a rationale for policy.' EPPE's research findings about families became more important over time. The findings on the family emerged because EPPE was a basic research project with a broad conceptual and methodological underpinning. Because the research was not focused exclusively on 'what works best in education?' (Humes \& Bryce 2001), the data were rich enough to draw conclusions about families as well as schools.

EPPE had an impact not only on the universal provision of education and care for all three and four year olds but also on a host of targeted social exclusion/inclusion initiatives. EPPE has informed policy because its findings are large scale and broadly representative (3,000 children and families), longitudinal (between 3 and age 11), and based on 'value added' methods that established the measurable contribution of pre-school education to children's academic and social/behavioural development. It could be argued that the EPPE research was 'pushing on an open door' in policy development in that its findings coincided with the need to develop early years education and care. While the time was ripe for major reforms to this non-statutory sector, the counterargument is that without this research evidence base, the extent and speed of the reform (made possible by the Treasury) would have been precarious. Because this research study was based on a knowledge exchange partnership between policy-makers and researchers, the policy teams were well informed about the findings and could use their details in shaping policy. This assured joint reporting to the public and confidence on the part of the architects of emerging policy. 


\section{Changing models of research}

\section{A Coda: Applying the Furlong and Oancea assessment framework}

This paper has argued that the EPPE study is a new form of partnership between researchers and policy-makers in England. How applicable is the Furlong and Oancea assessment framework (in press, this volume) to it? Some of its four dimensions of quality fit neatly - while others do not. The 'Epistemic' dimension fits EPPE quite well, although much of what the EPPE researchers consider important is hidden in what Furlong and Oancea call 'paradigm-dependent criteria'. The 'Capacity development' strand will be difficult to apply to this study because much information related to it is shrouded in the confidential operation of government. Details of the policy end of the partnership are not available, nor are details of deliberations higher up in government. Moreover it will be difficult to assess EPPE in terms of the personal growth of the partners; this dimension may be more relevant for research in which practitioners play a major role. Perhaps 'Capacity development' as a quality dimension is more relevant to a Research Assessment Exercise (RAE) model of assessment in the UK rather than a global and scientific one. Certain elements of the 'Technological' dimension are relevant to EPPE, especially those related to impact on policy or timeliness. However it will take years to establish the impact on learners and institutions because the scale of potential impact is vast and the effects of new programmes on children and families will take a decade to establish. Finally within the 'Economic' dimension, cost and auditability might be assessed for EPPE but marketability seems inappropriate when assessing a national research project funded by the government.

Applying the Furlong and Oancea framework to the EPPE research suggests that some aspects of it are more relevant to practitioner-based research than to other kinds; for example, 'collaboration', 'reflexivity' and 'personal growth' may be more important in small-scale, practitioner-based research than in large scale, quantitative studies. We hope that the framework evolves so that it is easily applicable to a broad range of research. The relative importance of each dimension and the 
weighting of criteria across the framework will need to vary when assessing different kinds of research. 


\section{Acknowledgements}

The EPPE research was funded by the DfES in the period 1996-2008. We are grateful to all the children, families and education staff who helped us. We are also grateful to the many fieldworkers on the project who assessed children, interviewed families and staff, and carried out systematic observations of practice. We also applaud the major work of the analysis team. However, most

important of all, we acknowledge the major contribution of our policy partners in government. (You know who you are!) 


\section{References}

Cabinet Office (1999). Modernising government white paper. London: HMSO.

Canadian Health Services Research Foundation (CHSRF; 2007). Glossary of knowledge exchange terms as used by the foundation. Available online at: http://www.chsrf.ca/home e.php (accessed 30 November 2006).

The Children Act (2004). HMSO, London.

Davies, H. T. O., Nutley, S. M. \& Smith, P. C. (1999). What works? The role of evidence in public sector policy and practice. Public Money \& Management, 19, 3-5.

Davies, H. T. O., Nutley, S. M. \& Smith, P. C. (Eds.). (2000). What works? Evidence-based policy and practice in public services. Bristol: The Policy Press.

DfES (2004). Ten Year Childcare Strategy, Choice for parents, the best start for children. DfES London.

DfES (2005). Primary National Strategy. KEEP: Key Elements of Effective Practice. London: Her Majesty's Stationary Office. Retrieved May 21, 2005, from The Standards Site:

http://www.standards.dfes.gov.uk/primary/publications/foundation_stage/keep/pns_fs120105 keep.pdf

The Equalities Review (2006). The Equalities Review. Available online at: http://www.theequalitiesreview.org.uk/ (accessed 30 November 2006).

Feuer, M. \& Smith, M. (2004). Toward Continuous Improvement of Research for Education Policy and Practice. Report for the National Educational Research Forum. NERF, January 2004.

Fitz-Gibbon, C. T. (1999). Education: high potential not realised. Public Money \& Management, 19, 33-40.

Furlong, J. \& Oancea, A. (in press). Assessing quality in applies and practice-based research in education: a framework for discussion. Research Papers in Education, this volume.

Gibbons, M., Limoges, C., Nowotny, H., Schwartzman, S., Scott, P. \& Trow, M. (1994). The New Production of Knowledge: the dynamics of science and research in contemporary societies. Sage.

Golden-Biddle, K., Reay, T., Petz, S., Witt, C., Casebeer, A., Pablo, A. \& Hinings, C. R. (2003). Toward a communicative perspective of collaborating in research: the case of researcherdecision-maker partnership. Journal of Health Services Research \& Policy, 8(Suppl. 2), 2025 . 
Hargreaves, A. \& Reynolds, D. (1989). Education Policies: Controversies and Critiques, Education Policy Perspectives Series. The Falmer Press: Lewes.

Hillage, J., Pearson, R., Anderson, A. \& Tamkin, P. (1998). Excellence in Research on Schools. London: DfES ('The Hillage Report').

HM Treasury (2007). Policy review of children and young people: A discussion paper. London: Her Majesty's Stationary Office.

HM Treasury (2003). Every Child Matters green paper. London: The Stationary Office. Retrieved September 12, 2004, from Every Child Matters Web site: http:/www.everychildmatters.gov.uk/ files/EBE7EEAC90382663E0D5BBF24C99A7AC.pd $\underline{f}$

House of Commons (2000). Education and employment committee. Early years. London: The Stationary Office.

House of Commons (2004). Early years: progress in developing high quality childcare and early education accessible to all. London: The Stationary Office.

Huberman, M. (1993). Linking the practitioner and researcher communities for school improvement. School Effectiveness and School Improvement, 4, 1-16.

Humes, W. \& Bryce, T. (2001). Scholarship, research and the evidential basis of policy development in education. In British Journal of Educational Studies, 49 (3).

Innvær, S., Vist, G.E., Trommald, M. \& Oxman, A. (2002). Health policy-makers' perceptions of their use of evidence: a systematic review. Journal of Health Services Research and Policy, 7, 230-244.

Inter-departmental Childcare Review: Delivering for children and families (2002).

DfES/Department for Work and Pensions/HM Treasury/Women and Equalities Unit. London: Strategy Unit Cabinet Office.

Liberal Democrats (2003). Early Years Consultation Paper No 65. London. ISBN 1851876979.

Macdonald, G. (1999). Evidence-based social care: wheels off the runway? Public Money \& Management, 19, 25-32.

Nutley, S. M., Percy-Smith, J. \& Solesbury, W. (2003). Models of research impact: a cross sector review of literature and practice. London: Learning and Skills Development Agency (LSDA).

Ross, S., Lavis, J., Rodriguez, C., Woodside, J. \& Denis, J-L. (2003). Partnership experiences: involving decision-makers in the research process. Journal of Health Services Research Policy, 8, 16-34. 
Sammons, P., Sylva, K., Melhuish, E. C., Siraj-Blatchford, I., Taggart, B. \& Elliot, K. (2002). The Effective Provision of Pre-School Education (EPPE) Project: Technical Paper 8 aMeasuring the Impact of Pre-School on Children's Cognitive Progress over the Pre-School Period. London: DfES / Institute of Education, University of London.

Sammons, P., Smees, R., Taggart, B., Sylva, K., Melhuish, E. C., Siraj-Blatchford, I. \& Elliot, K. (2002). The Early Years Transition and Special Educational Needs (EYTSEN) Project:

Technical Paper 1 - Special Needs Across the Pre-School Period. London: DfES / Institute of Education, University of London.

Sammons, P., Sylva, K., Melhuish, E. C., Siraj-Blatchford, I., Taggart, B. \& Elliot, K. (2003). The Effective Provision of Pre-School Education (EPPE) Project: Technical Paper $8 b$ Measuring the Impact of Pre-School on Children's Social/Behavioral Development over the Pre-School Period. London: DfES / Institute of Education, University of London.

Sammons, P., Taggart, B., Smees, R., Sylva, K., Melhuish, E., Siraj-Blatchford, I. \& Elliot, K. (2003a). The Early Years Transition and Special Educational Needs (EYTSEN) Project. DfES Research Brief No 431 June 2003. London: DfES Publications.

Sammons, P., Taggart, B., Smees, R., Sylva, K., Melhuish, E., Siraj-Blatchford, I. \& Elliot, K. (2003b). The Early Years Transition and Special Educational Needs (EYTSEN) Project DFES Research Report 431. Nottingham: Queens Press.

Sammons, P., Smees, R., Taggart, B., Sylva, K., Melhuish, E. C., Siraj-Blatchford, I. \& Elliot, K. (2004). The Early Years Transitions and Special Educational Needs (EYTSEN) Project: Technical Paper 2 - Special Educational Needs in the Early Primary Years: Primary school entry up to the end of Year 1. London: DfES / Institute of Education, University of London.

Sammons, P., Siraj-Blatchford, I., Sylva, K., Melhuish, E., Taggart, B. \& Elliot, K. (2005). Investigating the Effects of Pre-school Provision: Using Mixed methods in the EPPE Research. International Journal of Social Research Methodology, 8(3), 207-224.

Sebba, J. (2000). Using research evidence to reshape practice. Public Money and Management, 20, 8-10.

Siraj-Blatchford, I., Sammons, P., Sylva, K., Melhuish, E. \& Taggart, B. (2006). Educational Research and Evidence-based Policy: The Mixed Method Approach of the EPPE project. Evaluation and Research in Education, 19 (2), 63-82.

Siraj-Blatchford, I., Sylva, K., Muttock, S., Gilden, R. \& Bell, D. (2002), Researching Effective Pedagogy in the Early Years (REPEY): DfES Research Report 356. London: DfES, HMSO.

Siraj-Blatchford, I., Sylva, K., Taggart, B., Sammons, P., Melhuish, E. C. \& Elliot, K. (2003), The Effective Provision of Pre-School Education (EPPE) Project: Technical Paper 10 - Intensive Case Studies of Practice across the Foundation Stage, DfES Research Brief No RBX 16-03. Nottingham: DfES Publications. 


\section{Changing models of research}

Social Market Foundation (2005). Too Much, Too Late: Life Chances and Spending on Education and Training. London: SMF/Esmee Fairbairn. ISBN 1904899250.

Strategic Policy Making Team (1999). Professional policy making for the twenty-first century. London: The Cabinet Office.

Sure Start. (2006). A Code of Practice on the Provision of Free Nursery Education for Three and Four-Year-Olds. Nottinghamshire: DfES Publications. ISBN 1844786714.

Sylva, K. \& Pugh, G. (2005) Transforming the Early Years in England, Oxford Review of Education, $31,11-27$.

Sylva, K., Melhuish, E. C., Sammons, P., Siraj-Blatchford, I. \& Taggart, B. (2004). The Effective Provision of Pre-School Education (EPPE) Project: Final Report. London: DfES / Institute of Education, University of London.

Taggart, B., Sammons, P., Smees, R., Sylva, K., Melhuish, E. C., Siraj-Blatchford, I. \& Elliot, K. (2004). The Early Transition \& Special Educational Needs (EYTSEN) Project: Technical Paper 3 - The Parents' Perspective. London: DfES / Institute of Education, University of London

Taggart, B., Sammons, P., Smees, R., Sylva, K., Melhuish, E., Siraj-Blatchford, I., Elliot, K. \& Lunt, I. (2006). Early Identification of Special Needs and the Definition of 'At Risk': The Early Years Transition and Special Education Needs (EYTSEN) Project. British Journal of Special Education, 33, 40-45.

Tooley J. (1998). Educational Research: A Critique. Ofsted. London: HMSO.

Walter, I. (2005). Before and after: The role of providers in shaping the CYP\&SC research agenda and using research. Powerpoint presentation to the Scottish Executive, Edinburgh.

Walter, I, Davies, H. \& Nutley, S. (2003). Increasing research impact through partnerships: evidence from outside health care. Journal of Health Services Research and Policy, 8(Suppl. 2), 5861.

Walter, I., Nutley, S. \& Davies, H. (2003). Research impact: a cross sector review. Research Unit for Research Utilisation discussion paper. St Andrews: University of St Andrews. 

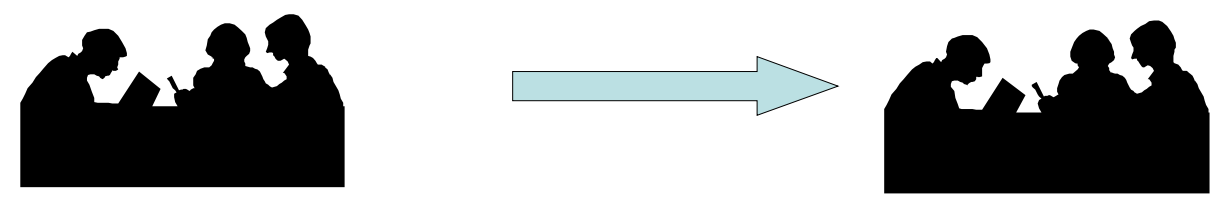

Figure 1 One-way linear transfer (Adapted from Walter, 2005) 

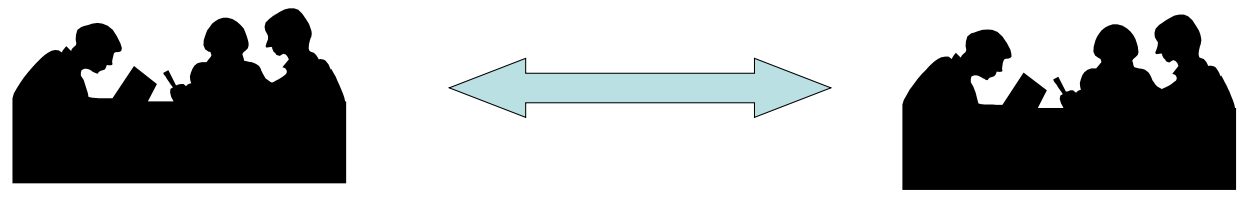

Figure 2 Two-way linear transfer (Adapted from Walter, 2005) 

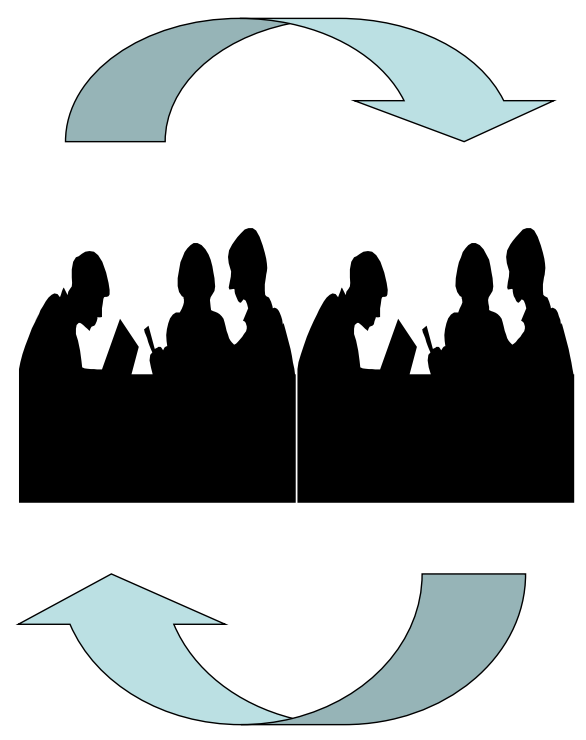

Figure 3 Knowledge exchange (Adapted from Walter, 2005) 